\title{
AC 2009-13: BENCHMARKING TWO URBAN MET BACHELOR PROGRAMS
}

Brian Vuksanovich, Youngstown State University

James Higley, Purdue University, Calumet 


\title{
Benchmarking Two Urban MET BS Programs
}

\begin{abstract}
Since the change to outcomes based accreditation in 2000, most engineering technology programs have adapted to the change and have implemented program outcomes and the accompanying assessment and evaluation techniques. TC2K created significant change in the engineering technology world, change that still has lasting effects eight years later. While the change to outcomes based assessment has not always been welcome, adapting to the change has caused many programs to become increasingly aware of what similar programs are doing in other parts of the country or even other parts of the world. A part of all strategic planning includes comparing oneself to one's competitors. In the educational world, we are not necessarily so concerned with competition but with improving and serving students. Hence, institutions frequently collaborate, so the term benchmarking is used for the initial comparison between programs. This paper benchmarks two urban Mechanical Engineering Technology programs and compares their background, objectives and outcomes, curriculum, and laboratories. It is hoped that this benchmark will encourage other programs to perform similar comparisons in an effort to improve and serve students.
\end{abstract}

\section{Introduction}

The Mechanical Engineering Technology programs at Youngstown State University ${ }^{1}$, Youngstown, Ohio (YSU) and Purdue University Calumet ${ }^{2}$ in Hammond, IN (PUC) share many similarities. Both institutions primarily serve regional, urban populations. Both programs have a long history of ABET accreditation dating back to the 1960s. Both programs have undergone recent ABET evaluations based on TC2K Criterion ${ }^{3}$.

There are differences as well. PUC has four full time, tenured faculty all at the full professor level while YSU has two assistant professors. PUC has approximately 130 MET majors while YSU has approximately 80. Also, while both programs serve urban areas, their focus has been different. YSU has long served the automotive and steel industries as its primary constituency while PUC has served the steel industry. Both automotive and steel industries have experienced difficulties, and both MET programs are placing graduates in more diverse areas with success.

\section{MET Program Objectives}

As part of the outcomes based assessment process, both programs developed program objectives independently. We define program objective to be the skills students possess after graduation as they enter the workforce. Table 1 below compares both programs. 
Table 1 - Program Objectives

\begin{tabular}{|c|c|}
\hline YSU & PUC \\
\hline $\begin{array}{l}\text { Graduates of the MET program at YSU will, } \\
\text { in their first several years of employment, } \\
\text { have the ability to: } \\
\text { 1. Work competently in technical and } \\
\text { professional careers related to the field of } \\
\text { Mechanical Engineering Technology } \\
\text { 2. Communicate effectively in a } \\
\text { professional environment } \\
\text { 3. Continue growth in professional } \\
\text { knowledge } \\
\text { 4. Achieve recognition and/or compensation } \\
\text { consistent with their educational } \\
\text { achievements. } \\
\text { In addition, } \\
\text { for two year graduates, } \\
\text { 'they immediately become productive in } \\
\text { careers involving design, drafting, testing, } \\
\text { and production of industrial machines and } \\
\text { consumer products.' } \\
\text { for Bachelor Degree graduates, } \\
\text { 'they are prepared for more responsibility } \\
\text { and more rapid advancement. Application- } \\
\text { oriented courses... prepare them for more } \\
\text { advanced design work, while courses } \\
\text { dealing with manufacturing systems } \\
\text { analysis, quality control, and industrial } \\
\text { management prepare them for supervisory } \\
\text { positions. }\end{array}$ & $\begin{array}{l}\text { The Mechanical Engineering Technology } \\
\text { Associate of Science program will produce } \\
\text { graduates that: } \\
\text { 1. Are prepared for successful careers in } \\
\text { the areas associated with the } \\
\text { fabrication, testing, documentation, } \\
\text { operation, sales, and maintenance of } \\
\text { basic mechanical systems. } \\
\text { 2. Advance in their careers and continue } \\
\text { their professional development. } \\
\text { 3. Understand the overall human context } \\
\text { in which engineering technology } \\
\text { activities take place. } \\
\text { In addition to the three objectives listed } \\
\text { above for the Associate of Science degree, } \\
\text { the Mechanical Engineering Technology } \\
\text { Bachelor of Science program will produce } \\
\text { graduates that: } \\
\text { 4. Are prepared for successful careers in } \\
\text { the areas associated with the analysis, } \\
\text { applied design, development, } \\
\text { implementation, and oversight of more } \\
\text { advanced mechanical systems and } \\
\text { processes. }\end{array}$ \\
\hline
\end{tabular}

While YSU lists one set of objectives, PUC separates out specific technical objectives between the AS and BS programs. Taken as a whole, the two sets of objectives are reasonably consistent. YSU specifically calls out communication objectives while PUC emphasizes human context. Both sets of objectives emphasize the importance of successful careers and future growth.

\section{Program Outcomes}

Again, both programs developed MET Program Outcomes independently. Here, we define a program outcome as a skill the students possess at the conclusion of program. Table 2 compares the outcomes from each program. 
Table 2 - Program Outcomes

\begin{tabular}{|c|c|}
\hline YSU & PUC \\
\hline $\begin{array}{l}\text { 1. be able to apply principles of } \\
\text { mathematics and applied science, to } \\
\text { perform technical calculations and } \\
\text { solve technical problems of the types } \\
\text { commonly encountered in mechanical } \\
\text { engineering technology careers. } \\
\text { (consistent with TAC/ABET Criterion } \\
2 \text { Outcomes a, b, f); } \\
\text { 2. demonstrate the ability to identify, } \\
\text { formulate, and present creative } \\
\text { solutions to technical problems in a } \\
\text { variety of specialty areas within the } \\
\text { broad field of mechanical engineering } \\
\text { technology. (consistent with } \\
\text { TAC/ABET Criterion } 2 \text { Outcome d); } \\
\text { 3. be able to function competently in a } \\
\text { laboratory setting, making } \\
\text { measurements, operating technical } \\
\text { equipment, critically examining } \\
\text { experimental results, and properly } \\
\text { reporting on experimental results, } \\
\text { including their potential for process } \\
\text { improvement. (consistent with } \\
\text { TAC/ABET Criterion } 2 \text { Outcomes a, b, } \\
\text { c, f, g); } \\
\text { 4. be able to use modern computational } \\
\text { tools for technical problem solving, } \\
\text { including scientific calculators, } \\
\text { computers and appropriate software. } \\
\text { (consistent with TAC/ABET Criterion } \\
2 \text { Outcomes a, b, f); } \\
\text { 5. demonstrate a broad education and } \\
\text { knowledge of contemporary issues in a } \\
\text { global and societal context, as } \\
\text { necessary to develop professional and } \\
\text { ethical responsibility, including } \\
\text { responsibility to employers and to } \\
\text { society at large. (consistent with } \\
\text { TAC/ABET Criterion } 2 \text { Outcomes i, j); } \\
\text { recognize the need for life-long } \\
\text { learning, especially concerning } \\
\text { maintenance and improvement of } \\
\text { technical skills (consistent with } \\
\text { TAC/ABET Criterion } 2 \text { Outcome h); \& }\end{array}$ & $\begin{array}{l}\text { 1.1.Students will demonstrate proficiency } \\
\text { in mechanical design, materials, } \\
\text { manufacturing processes, mechanics, } \\
\text { and fluid power. (a, b, c, d, f)* } \\
\text { 1.2.Students will demonstrate proficiency } \\
\text { in applied mathematics and science. (b, } \\
\text { c, f)* } \\
\text { 1.3.Students will demonstrate proficiency } \\
\text { in computer applications. (a, d, g)* } \\
\text { 1.4.Students will demonstrate proficiency } \\
\text { in solving open-ended problems } \\
\text { requiring multiple areas of knowledge. } \\
\text { (a, b, c, d, f)* } \\
\text { 2.1.Students will demonstrate a level of } \\
\text { effectiveness expected by employers } \\
\text { when they produce written documents, } \\
\text { deliver oral presentations, and develop, } \\
\text { prepare and interpret visual } \\
\text { information. (a, g, i) } \\
\text { 2.2.Students will be exposed to the value of } \\
\text { professional societies in their careers. } \\
\text { (h) } \\
\text { 2.3.Students will demonstrate proficiency } \\
\text { in managing projects. (e, f, g, i, j) } \\
\text { 2.4.Students will understand the } \\
\text { advantages of self-learning. (h, k) } \\
\text { 3.1.Students will have exposure to } \\
\text { situations that develop a sense of } \\
\text { personal responsibility and } \\
\text { accountability for one's individual } \\
\text { actions and performance. (i, } \mathrm{k} \text { ) } \\
\text { 3.2.Students will have exposure to } \\
\text { situations that develop their philosophy } \\
\text { and appreciation for human differences. } \\
\text { (i, j) } \\
\text { 3.3.Students will be able to demonstrate the } \\
\text { ability to communicate in individual } \\
\text { and team settings. (e, g) } \\
\text { 3.4.Students will demonstrate proficiency } \\
\text { in assisting others in a group. (e, g) } \\
\text { 4.1.Students will demonstrate proficiency } \\
\text { in mechanical design, materials, } \\
\text { manufacturing processes, mechanics, } \\
\text { fluid dynamics, and heat and power.( } a \text {, }\end{array}$ \\
\hline
\end{tabular}




\begin{tabular}{|c|c|}
\hline $\begin{array}{l}\text { 7. demonstrate an ability to communicate } \\
\text { effectively and function effectively } \\
\text { with members of multi-disciplinary } \\
\text { teams and with other workers in an } \\
\text { industrial setting, including those from } \\
\text { a variety of backgrounds. (consistent } \\
\text { with TAC/ABET Criterion } 2 \text { Outcomes } \\
\mathrm{e}, \mathrm{g}, \mathrm{j}) \text {. } \\
\text { Program outcomes for the } \\
\text { Associate's and Bachelor's Degrees } \\
\text { differ only in that the Bachelor's } \\
\text { Degree has expectations of greater } \\
\text { extent of achievement }\end{array}$ & $\begin{array}{l}\mathrm{b}, \mathrm{c}, \mathrm{d}, \mathrm{f})^{*} \\
\text { 4.2.Students will demonstrate proficiency } \\
\text { in applied mathematics and science.( } \mathrm{b} \text {, } \\
\mathrm{c}, \mathrm{f})^{*} \\
\text { 4.3. Students will demonstrate proficiency } \\
\text { in computer applications. }(\mathrm{a}, \mathrm{d}, \mathrm{g})^{*} \\
\text { 4.4.Students will demonstrate proficiency } \\
\text { in solving open-ended problems } \\
\text { requiring multiple areas of knowledge.( } \\
\mathrm{a}, \mathrm{b}, \mathrm{c}, \mathrm{d}, \mathrm{f})^{*}\end{array}$ \\
\hline
\end{tabular}

Since both sets of outcomes are based on the TAC of ABET a-k criterion, one would expect the similarities obvious from Table 2. The only noticeable difference is the PUC outcome 3.4, students will demonstrate proficiency in assisting others in a group. In addition, PUC details out the outcomes in somewhat more detail.

\section{Curriculum}

The following Tables 3 and 4 list the YSU curriculum in semester by semester format, and the courses are placed in the appropriate category as described by ABET Criterion 4. Tables 5 and 6 list the same for PUC. 
Table 3 - YSU AS Curriculum

\begin{tabular}{|c|c|c|c|c|c|c|}
\hline \multirow[b]{2}{*}{$\begin{array}{l}\text { Year and } \\
\text { Semester } \\
\text { (typical } \\
\text { offering) }\end{array}$} & \multirow[b]{2}{*}{$\begin{array}{c}\text { Table 1A Curriculum } \\
\text { Associate Degree } \\
\text { Courses } \\
\text { (Department, Number, Title) }\end{array}$} & \multicolumn{5}{|c|}{ Category (Credit Hours } \\
\hline & & 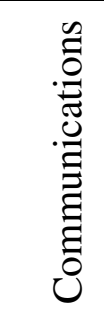 & 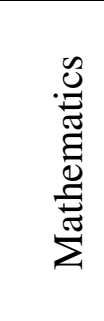 & 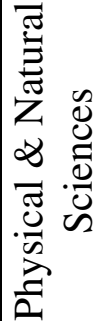 & 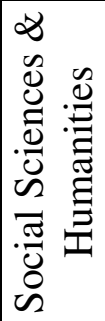 & 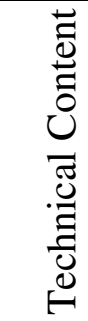 \\
\hline 1st, Fall & STECH 1505 Intro. to Engr. Tech. & & & & & 3 \\
\hline 1st, Fall & MATH 1513 Alg./Trans. Functions & & 5 & & & \\
\hline 1st, Fall & DDT 1505 CAD Technology & & & & & 4 \\
\hline 1st, Fall & ENGL 1551 Writing 1 & 3 & & & & \\
\hline 1st, Fall & GER elective: Pers./Soc. Responsibility & & & & 3 & \\
\hline 1st, Spring & MET 1515 Mechanics 1 & & & & & 3 \\
\hline 1st, Spring & CCET 2604 Prop./Strength of Mat'ls & & & & & 3 \\
\hline 1 st, Spring & CCET 2614 Materials Lab & & & & & 1 \\
\hline 1 st, Spring & PHYS 1501 Fund's of Physics 1 & & & 4 & & \\
\hline 1 st, Spring & PHYS 1501L Fund's of Phys 1 Lab & & & 1 & & \\
\hline 1st, Spring & ENGL 1551 Writing 2 & 3 & & & & \\
\hline 2nd, Fall & MATH 1570 Applied Calculus 1 & & 4 & & & \\
\hline 2nd, Fall & PHYS 1502 Fund's of Physics 2 & & & 3 & & \\
\hline 2nd, Fall & PHYS 1502L Fund's of Physics 2 Lab & & & 1 & & \\
\hline 2nd, Fall & MET 3714 Fluid Mechanics & & & & & 2 \\
\hline 2nd, Fall & MET 3714L Fluids Mechanics Lab & & & & & 1 \\
\hline 2nd, Fall & MET 2616 Mechanics 2 & & & & & 3 \\
\hline 2nd, Fall & MET 3706 Machine Design 1 & & & & & 3 \\
\hline 2nd, Spring & MET 3705 Thermodynamics & & & & & 3 \\
\hline 2nd, Spring & MET 2630 Manufacturing Techniques & & & & & 2 \\
\hline 2nd, Spring & MET 2630L Manufacturing Techniques Lab & & & & & 1 \\
\hline 2nd, Spring & MET 3707 Machine Design 2 & & & & & 3 \\
\hline 2nd, Spring & DDT 2606 CAD Technology 2 & & & & & 4 \\
\hline 2nd, Spring & $\begin{array}{l}\text { COMST } 1545 \text { Communication Theory \& } \\
\text { Practice }\end{array}$ & 3 & & & & \\
\hline 2nd, Spring & GER Elective: Societies \& Institutions & & & & 3 & \\
\hline & TALS for ASSOCIATE'S DEGREE & 9 & 9 & 9 & 6 & 36 \\
\hline & PERCENT OF TOTAL & 13.0 & 13.0 & 13.0 & 8.7 & 52.2 \\
\hline
\end{tabular}


Table 4 - YSU BS Curriculum

\begin{tabular}{|c|c|c|c|c|c|c|}
\hline \multirow[b]{2}{*}{$\begin{array}{l}\text { Year and } \\
\text { Semester } \\
\text { (typical } \\
\text { offering) }\end{array}$} & \multirow[b]{2}{*}{$\begin{array}{l}\text { Table 1B Curriculum } \\
\text { Bachelor's Degree } \\
\text { Courses } \\
\text { (Department, Number, Title) }\end{array}$} & \multicolumn{5}{|c|}{ Category (Credit Hours } \\
\hline & & 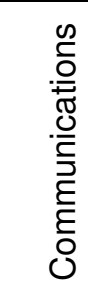 & 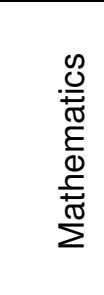 & 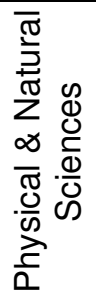 & 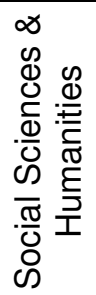 & 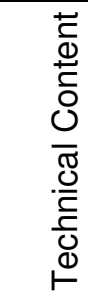 \\
\hline 3rd, Fall & MATH 2670 Applied Calculus 2 & & 5 & & & \\
\hline 3rd, Fall & EET 3725 Electromechanical Systems & & & & & 4 \\
\hline 3rd, Fall & MET 3711 Heat \& Power Cycles & & & & & 3 \\
\hline 3rd, Fall & ISEGR/MGT Elective & & & & & 3 \\
\hline 3rd, Fall & MET Elective & & & & & 3 \\
\hline 3rd, Spring & MET 3700 Physical Measurements & & & & & 3 \\
\hline 3rd, Spring & MET 3715 Fluid Power & & & & & 3 \\
\hline 3rd, Spring & MET 3720 Mechanisms & & & & & 3 \\
\hline 3rd, Spring & CCET 3705 Computing for Technologists & & & & & 3 \\
\hline 3rd, Spring & $\begin{array}{lrlll}\text { GER Elective: } & \text { Personal } & \& & \text { Social } \\
\text { Responsibility } & & & \\
\end{array}$ & & & & 3 & \\
\hline 4th, Fall & MET 4820 Machine Systems & & & & & 3 \\
\hline 4th, Fall & MET 4810 Manufacturing Systems Analysis & & & & & 3 \\
\hline 4th, Fall & MET Elective & & & & & 3 \\
\hline 4th, Fall & CHEM Elective & & & 3 & & \\
\hline 4th, Fall & CHEM Elective, matching lab & & & 1 & & \\
\hline 4th, Fall & GER Elective: Societies \& Institutions & & & & 3 & \\
\hline 4th, Spring & MET 4870 Applied Finite Element Method & & & & & 3 \\
\hline 4th, Spring & MET 4860 Robotics Technology & & & & & 2 \\
\hline 4th, Spring & MET 4860L Robotics Technology Lab & & & & & 1 \\
\hline 4th, Spring & $\begin{array}{llll}\text { GER Elective: } & \text { Artistic } \& \text { Literary } \\
\text { Perspectives }\end{array}$ & & & & 3 & \\
\hline 4th, Spring & $\begin{array}{llll}\text { GER Elective: } & \text { Artistic } \& \text { Literary } \\
\text { Perspectives }\end{array}$ & & & & 3 & \\
\hline 4th, Spring & $\begin{array}{l}\text { GER Elective: Artistic \& L Literary } \\
\text { Perspectives } \text { or } \text { Societies \& Institutions }\end{array}$ & & & & 3 & \\
\hline TOTAL & $\begin{array}{l}\text { R BACHELOR'S DEGREE (includes AAS } \\
\text { credits) }\end{array}$ & 9 & 14 & 13 & 21 & 76 \\
\hline & PERCENT OF TOTAL & 6.8 & 10.5 & 9.8 & 15.8 & 57.1 \\
\hline
\end{tabular}


Table 5 - PUC AS MET Curriculum

\begin{tabular}{|c|c|c|c|c|c|c|}
\hline \multirow[b]{2}{*}{$\begin{array}{l}\text { Year and } \\
\text { Semester } \\
\text { (or } \\
\text { Quarter) }\end{array}$} & \multirow[b]{2}{*}{$\begin{array}{c}\text { Course } \\
\text { (Department, Number, Title) }\end{array}$} & \multicolumn{5}{|c|}{ Category (Credit Hours) } \\
\hline & & 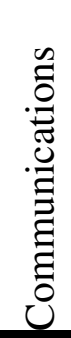 & 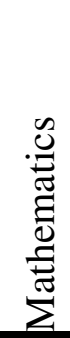 & 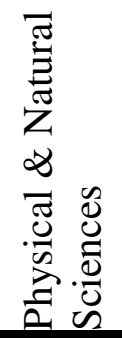 & 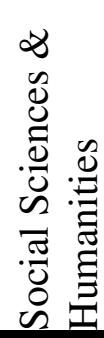 & 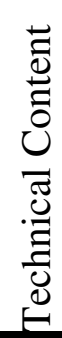 \\
\hline 1 , fall & MA-147 Algebra \& Trig for Tech I & & 3 & & & \\
\hline 1, fall & ENGL-104 English Composition & 3 & & & & \\
\hline 1 , fall & $\begin{array}{l}\text { MET-161 Intro to Engineering } \\
\text { Technology }\end{array}$ & & & & & 3 \\
\hline 1 , fall & $\begin{array}{l}\text { CGT-110 Technical Graphics } \\
\text { Communication }\end{array}$ & & & & & 3 \\
\hline 1, fall & MET-242 Manufacturing Processes II & & & & & 3 \\
\hline 1 , spring & MA148 Algebra \& Trig for Tech II & & 3 & & & \\
\hline 1, spring & MET-118 Statics & & & & & 3 \\
\hline 1, spring & MET-141 Manufacturing Materials I & & & & & 3 \\
\hline 1 , spring & ENGL-220 Technical Report Writing & 3 & & & & \\
\hline 1 , spring & $\begin{array}{l}\text { MET-162 Comp. Analysis Tools in } \\
\text { MET }\end{array}$ & & & & & 1 \\
\hline 1 , spring & COM-114 Fund/Speech Comm. & 3 & & & & \\
\hline 2, fall & MA-221 Calculus for Technology I & & 4 & & & \\
\hline 2, fall & $\begin{array}{l}\text { MET-211 Applied Strength of } \\
\text { Materials }\end{array}$ & & & & & 3 \\
\hline 2 , fall & \begin{tabular}{|l|} 
PHYS-220 General Physics I \\
\end{tabular} & & & 4 & & \\
\hline 2, fall & MET-205 Production Design \& CAD II & & & & & 3 \\
\hline 2 , fall & MET-213 Dynamics & & & & & 3 \\
\hline 2 , spring & PHYS-221 General Physics II & & & 4 & & \\
\hline 2 , spring & MET-230 Fluid Power & & & & & 3 \\
\hline 2 , spring & POL-305 Technology \& Society & & & & 3 & \\
\hline 2 , spring & MET-214 Machine Elements & & & & & 3 \\
\hline 2 , spring & $\begin{array}{l}\text { MET-266 Strength of Materials/Testing } \\
\text { Laboratory }\end{array}$ & & & & & 3 \\
\hline TOTALS $\mathrm{F}$ & EQUIRED FOR DEGREE & 9 & 10 & 8 & 3 & 34 \\
\hline PERCENT & OF TOTAL & 14 & 15 & 13 & 5 & 53 \\
\hline
\end{tabular}


Table 6 - PUC BS MET Curriculum

\begin{tabular}{|c|c|c|c|c|c|c|}
\hline \multirow[b]{2}{*}{$\begin{array}{l}\text { Year and } \\
\text { Semester } \\
\quad \text { (or } \\
\text { Quarter) }\end{array}$} & \multirow[b]{2}{*}{$\begin{array}{c}\text { Course } \\
\text { (Department, Number, Title) }\end{array}$} & \multicolumn{5}{|c|}{ Category (Credit Hours) } \\
\hline & & 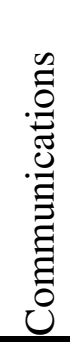 & 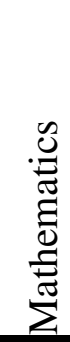 & 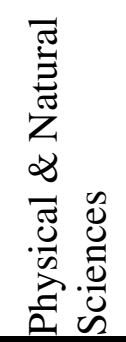 & 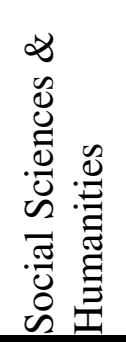 & 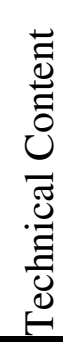 \\
\hline 3 , fall & MET Elective & & & & & 3 \\
\hline 3 , fall & $\begin{array}{l}\text { STAT-301 Elementary Statistical } \\
\text { Methods }\end{array}$ & & 3 & & & \\
\hline 3 , fall & Free Elective & & & & & \\
\hline 3 , fall & MET-325 Applied Thermodynamics I & & & & & 3 \\
\hline 3, fall & Technical Elective & & & & & 3 \\
\hline 3 , fall & MA-222 Calculus for Technology II & & 3 & & & \\
\hline 3 , spring & ECET-214 Electricity Fundamentals & & & & & 3 \\
\hline 3 , spring & MET-313 Applied Fluid Mechanics & & & & & 3 \\
\hline 3 , spring & CHEM-111 General Chemistry & & & 3 & & \\
\hline 3, spring & IET-22 Production Planning \& Control & & & & & 3 \\
\hline 3 , spring & MET-329 Applied Heat Transfer & & & & & 3 \\
\hline 4, fall & $\begin{array}{l}\text { IET-308 Engineering Project } \\
\text { Management and Economic Analysis }\end{array}$ & & & & & 3 \\
\hline 4 , fall & $\begin{array}{l}\text { MET-461 Computer Integrated Design } \\
\text { \& Manufacturing }\end{array}$ & & & & & 3 \\
\hline 4 , fall & ENGL-420 Business Writing & 3 & & & & \\
\hline 4, fall & OLS-331 Occupational Safety \& Health & & & & & 3 \\
\hline 4 , fall & MET-495 Senior Project Survey & & & & & 1 \\
\hline 4, fall & General Education Elective & & & & 3 & \\
\hline 4, spring & Technical Elective & & & & & 3 \\
\hline 4 , spring & $\begin{array}{l}\text { OLS-474 Conference Leadership } \\
\text { Training }\end{array}$ & 3 & & & & \\
\hline 4, spring & MET Elective & & & & & 3 \\
\hline 4, spring & MET-497 Senior Project & & & & & 3 \\
\hline 4, spring & General Education Elective & & & & 3 & \\
\hline TOTALS & REQUIRED FOR DEGREE & 15 & 16 & 11 & 9 & 74 \\
\hline PERCENT & OF TOTAL & 12 & 12 & 9 & 7 & 58 \\
\hline
\end{tabular}

At the AS level, the most noticeable difference is that YSU has 69 credit hours while PUC has only 64. YSU has one more 3 credit hour general education course and an additional machine design course that PUC does not include. Interestingly, YSU offers thermodynamics as a second semester sophomore course while PUC offers a separate materials course. The percentage break down in the communications, mathematics, science, general education, and technical areas are very similar except for YSU's additional general education percentage. 
YSU is currently assessing the current its general education policy. There is concern that the current policy is not achieving the original objectives that were set out when the policy was implemented. As the assessment is on-going, it is too soon to report on what action will be taken. The Engineering Technology program is supporting a general education percentage more in line with PUC's. This position is based on input from the MET Industrial Advisory Board (IAB), surveys of alumni working in the discipline, comparisons to similar programs elsewhere and evaluations of required course material content required to meet program objectives and outcomes. The trend seems to indicate that graduates need to be more technically versed to keep their employers competitive. While communication skills are still considered very valuable, there is mounting evidence supporting a reduction in the quantity of general education and an increase in discipline related classes.

At the BS level, YSU requires 133 credit hours while PUC requires 125 . PUC requires 15 credit hours of communications while YSU requires 9. Math, science, and technical areas agree within a few credit hours. Most of YSU's additional hours are in social sciences/humanities with 21 hours required while PUC requires 9. In the technical areas, YSU shows a greater concentration in the area of automation while PUC emphasizes project management, OSHA, and technical electives. Perhaps the largest area of difference is the capstone project. PUC uses a four credit hour two course sequence where the students propose and then complete an open ended project. YSU uses the MET 4860 course as the capstone with an open ended project as part of the course material.

PUC's capstone class is similar to a program that is being initiated at YSU. Both involve proposing then solving an open-ended problem. YSU differs in that a priority has been put on fostering innovation, creativity and collaboration with diverse groups earlier in the students' career. The plan is to team MET students with students from Fine and Performing Arts (FPA) in an environment where an open-ended problem can be worked using the strengths from both schools. MET students get exposure to loosely defined problems with many possible workable solutions, gaining experience in synthesis in addition to traditional analysis based work. Communication and diversity of perspective also play out naturally while giving FPA students a hands-on introduction to the engineering technology field. Pilot projects have shown a marked increase in MET students' performance with minimal cost to the department.

It is notable that both programs seem to value open-ended problems, communications and collaboration. While the approach is somewhat different, it seems that the goals are similar. YSU's proposed pedagogical method may be an incremental improvement over PUC's, but this still needs to be assessed with more data. These pedagogical methods seem to be consistent with other similar programs currently showing merit such as:

- $\quad$ AME Center - Arizona State University; Arts, Media and Engineering

○ Team-based research

$\circ$ Diverse expertise covering the full scope of the human experience

○ Interdisciplinary, multi-instructor courses

- Emphasis on collective excellence

- $\quad$ The Keller Center - Princeton; Entrepreneurship, Leadership

○ Gain exposure to real-world engineering problems

- Be able to solve problems from an interdisciplinary perspective 
○ Understand technology in its societal context

- $\quad$ Converging Technologies - Union College; Engineering \& Liberal Arts

$\circ$ focuses creative thought from engineering and the liberal arts on new ideas

\section{Textbooks}

The textbooks used by both programs are comparable and at the same academic level. Select representative books are listed below for comparison.

Manufacturing Technology - Sophomore

PUC - Manufacturing Engineering and Technology $5^{\text {th }}$ ed., Kalpakjian

Engineering Level

YSU - Materials \& Processes in Manufacturing $10^{\text {th }}$ ed., DeGarmo

Engineering Level

Machine Design/Analysis - Sophomore

PUC \& YSU - Machine Elements in Mechanical Design $4^{\text {th }}$ ed., Mott

Technologist Level - no calculus

Fluid Mechanics - Sophomore \& Junior

PUC \& YSU - Applied Fluid Mechanics $6^{\text {th }}$ ed., Mott

Technologist Level - no calculus

The book selection shows no significant difference between the two programs. The books seem to be of similar level with equal levels of mathematical requirements. It should be noted that the math requirements of both programs are the same with equal classes in algebra and calculus even though these texts are outside the scope of this comparison.

\section{Laboratory Development Efforts}

As technology programs, both YSU and PUC have large dedicated laboratories so students get practical, hands on experience as part of their education. Tables 7 and 8 list the laboratories for the two programs.

Table 7 - YSU Laboratories

\begin{tabular}{|l|l|l|l|}
\hline Laboratory & Building & $\underline{\text { Room }}$ & $\underline{\text { Area (Sq. Ft.) }}$ \\
\hline Mechanical Lab & Moser Hall & 4190 & 1120 \\
\hline Mechanical Lab & Moser Hall & 4160 & 550 \\
\hline Fluids Lab & Moser Hall & 0325 & 4900 \\
\hline ET Computer Lab & Moser Hall & 4050 & 550 \\
\hline Civil Tech. Lab & Moser Hall & 4180 & 1150 \\
\hline Strength Lab & Moser Hall & 0400 & 3675 \\
\hline Machine Shop & Moser Hall & 0050 & 1876 \\
\hline Robotics Lab & Moser Hall & 0060 & 1400 \\
\hline $\begin{array}{l}\text { CAD Drawing/PC } \\
\text { Lab }\end{array}$ & Moser Hall & 4200 & 1150 \\
\hline
\end{tabular}


Table 8 - PUC Laboratories

\begin{tabular}{|l|l|l|l|}
\hline Laboratory & Building & $\underline{\text { Room }}$ & Area (Sq. Ft.) \\
\hline Manufacturing Lab & Anderson & 140 & 4000 \\
\hline Quality Control & Anderson & 145 & \\
\hline Materials Testing & Anderson & 149 & \\
\hline CAD & Anderson & 216 & \\
\hline Fluid Power & Anderson & 217 & \\
\hline CAD & Anderson & 220 & \\
\hline Integrated Design & Anderson & 229 & \\
\hline $\begin{array}{l}\text { Industrial } \\
\text { Engineering } \\
\text { Technology }\end{array}$ & Anderson & 244 & \\
\hline
\end{tabular}

\section{Faculty}

The previous comparison of the capstone classes highlights an important difference in the circumstances that each department is in. The YSU MET program has $62 \%$ the enrollment that PUC has while PUC has twice the number of full-time tenured faculty. Both of YSU's full-time faculty are recently hired pre-tenure. This seems to have resulted in a lag between YSU and PUC regarding the implementation of updated pedagogical techniques. YSU experienced a turnover in faculty in Fall 2006 where both MET full-time faculty members left and two new junior faculty members were brought in. Coming from industry, the traditions and unique idiosyncrasies of academia needed to be learned before curricular progress could be made. Comparisons such as this one involving assistance from other programs and faculty has proved to be a significant help in adapting to the academic environment in addition to providing invaluable insight to class improvements. Key to these improvements was leveraging recent industry experience and bringing it into the classroom.

\section{Assessment}

Assessment of the two programs follows similar lines. Since both are ABET accredited, assessment criteria are the same. Within the ABET assessment framework, there are some differences in the programs that come from the geographical and economic regions each program serves. These regions' needs are largely determined by regular meetings of the respective Industrial Advisory Boards (IAB) as required by ABET. Since these boards are comprised of members of local industry representatives, the specific concerns between the two programs vary. The variation shows that the IAB has value in communicating societies' needs to the program.

Both programs convene IAB meetings at least once a year. Participants are selected from local industry. Participants whose academic background is from a different university is valued so that ideological inbreeding can be avoided. Also, those that have recently and/or regularly hire graduates from each program provide current insight into successes or failures of new pedagogy as it relates to them. Complaints are discussed with possible solutions and successes are analyzed for application to other issues. Program coordinators collect the data and, with other faculty, determine a course of action to address issues and concerns. The internal assessment data that each faculty member records during the year is also incorporated into the process. When 
significant changes are proposed, the IAB may be reconvened to review the changes and offer suggestions.

\section{Conclusion}

The MET programs at Youngstown State University and Purdue University Calumet show remarkable similarities as one might expect from two ABET accredited programs. The primary differences are YSU's additional credit hours, primarily from general education requirements. The technical areas are very similar with YSU concentrating on machine design and automation while PUC moves more into project management and related areas. As part of this benchmarking activity, PUC is looking to see if more technical content similar to YSU's automation area might be appropriate. YSU is considering a more formal senior project as PUC has. All of this comes from continuous improvement, and benchmarking is just one step in the process.

\section{Bibliography}

1. Youngstown State University Mechanical Engineering Technology website, http://www.eng.ysu.edu/programs/tech/Programs/MET.htm

2. Purdue University Calumet Mechanical Engineering Technology website, http://webs.calumet.purdue.edu/et/eng-tech/mechanical-engineering-technology-program-overview/

3. Accreditation Board for Engineering and Technology website, http://www.abet.org/ 